\title{
General Psychiatry Acute oedema associated with risperidone use: a report
}

\author{
Arpita Thakur, ${ }^{1}$ Vijay Niranjan, ${ }^{1}$ Pali Rastogi, ${ }^{2}$ Ramghulam Razdan ${ }^{1}$
}

To cite: Thakur A, Niranjan V, Rastogi $\mathrm{P}$, et al. Acute oedema associated with risperidone use: a report. General Psychiatry 2020;33:e100203. doi:10.1136/ gpsych-2020-100203

Received 30 January 2020 Revised 13 May 2020 Accepted 01 June 2020
Check for updates

(C) Author(s) (or their employer(s)) 2020. Re-use permitted under CC BY-NC. No commercial re-use. See rights and permissions. Published by BMJ.

${ }^{1}$ Department of Psychiatry, Mahatma Gandhi Memorial Medical College, Indore, Madhya Pradesh, India

${ }^{2}$ Department of Psychiatry, MGM Medical College Indore, Indore, Madhya Pradesh, India

Correspondence to Dr Arpita Thakur; dr.arpitathakur@gmail.com

\section{ABSTRACT}

Risperidone acts by potent serotonergic, dopaminergic and alpha adrenergic receptor antagonism. The most common side effects reported are extrapyramidal symptoms, dizziness, sedation, insomnia, headache, anxiety, nausea, constipation and weight gain. Oedema associated with risperidone use is a rare side effect. Here we present a report on pedal oedema associated with use of oral risperidone $4 \mathrm{mg}$ per day for acute-onset psychotic illness. Through this case report we want to make clinicians aware about this important side effect as it can affect patients' compliance and quality of life.

\section{INTRODUCTION}

Risperidone, a second-generation atypical antipsychotic which was introduced in 1993, is a benzoxazole derivative. It acts by potent serotonergic (5 Hydroxy Tyrptamine-2), dopaminergic (D2 receptor) and adrenergic (alpha 1) receptor antagonism. The most common side effects reported with risperidone are extrapyramidal symptoms, dizziness, sedation, insomnia, headache, anxiety, nausea, constipation and weight gain. However, oedema associated with risperidone use is a rarely reported side effect in the literature. We present a case report on pedal oedema associated with use of risperidone which subsided after decreasing the dose.

\section{CASE HISTORY}

A 35-year-old male patient came to our outpatient department with complaints of aggressive behaviour, suspiciousness and gesticulatory behaviour for the last 25 days, with unremarkable medical and psychiatric history. Symptoms were acute in onset. A diagnosis of acute and transient psychotic disorder was made and he was prescribed risperidone tablet $4 \mathrm{mg}$ orally in divided doses. The patient came back after 1 week with a complaint of bilateral below-knee pedal oedema (figure 1). The family members reported that the oedema appeared 2-3 days prior and had been gradually progressive since then. On physical examination, his feet, ankles and pretibial region were grade $2+$ oedematous. There was a slight pitting oedema in the distal twothirds of the pretibial region which gradually increased towards the feet. Physical examination excluded any other pathology or organomegaly. Complete laboratory examinations were done including complete blood count, serum electrolytes, liver function test, renal function test, thyroid function test, rheumatological test, immunological examination and urine analysis. All reports were within normal limits. ECG and chest radiography did not reveal any pathology. A cardiologist and nephrologist were consulted to rule out any pathology. Physician opinion was taken to rule out other medical causes of oedema, but they could not conclude any definite medical cause for the same. The patient's behavioural symptoms were significantly reduced, so we decided to reduce the dose of risperidone to $2 \mathrm{mg}$ /day after keeping in mind the previous dose-dependent nature of this adverse effect, which is reported in the literature. The oedema gradually subsided after decreasing the dose of risperidone and completely resolved over 1 week. The patient was then maintained on this dose of risperidone and was followed up for a year without any further complication. As per Naranjo Adverse Drug Reaction Probability Scale, the rating for the index case was 7, which corresponds to probable adverse drug reaction associated with risperidone. ${ }^{1}$

\section{DISCUSSION}

Oedema is a rare complication associated with risperidone. There have been some case reports showing the occurrence of oedema in a dose-dependent manner with risperidone therapy. In a randomised, double-blind study which compared risperidone with placebo for treatment of psychosis, Katz et $a t^{2}$ found that $15.8 \%$ of 462 subjects who received risperidone developed peripheral oedema in a dose-related fashion as compared with $5.5 \%$ of placebo cases. This was the only study reporting such high incidence of oedema after risperidone use in the literature. 


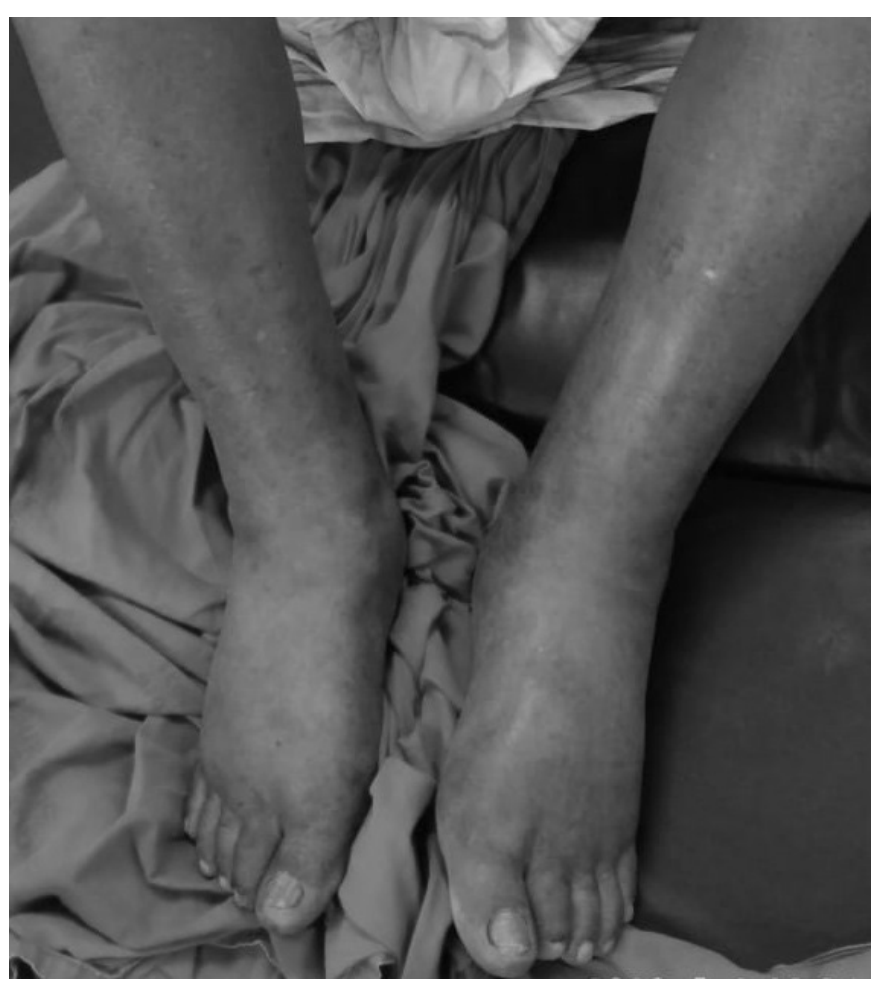

Figure 1 Bilateral pedal oedema associated with risperidone treatment.

However, the result of this study should be interpreted cautiously, as the subjects included in the study were aged more than 82 years, so the oedema might be related to the diminished physical status of these patients.

Sanders and Lehrer ${ }^{3}$ reported a case in which oedema appeared after adding risperidone in a patient who was already on a regimen including valproic acid and a benzodiazepine. Although there are previous published reports in the literature regarding oedema associated with risperidone use, our case was distinct in that the oedema rapidly developed in less than a week period, while in other reports the period of development was slightly longer, ranging from 2 weeks to 3 months, except for a case reported by Ravasia ${ }^{4}$ where oedema developed in just 3 days with a low dose of risperidone. Also there were no other risk factors in our case, such as elderly age, concomitant use of other drug or family history of angiooedema, as present in a few other reported cases.

Although the exact mechanism of this side effect is unclear, it can be explained with several mechanisms that could be responsible for oedema after using risperidone. As per the supersensitivity and vasodilatation theory, risperidone acts as antagonist to the alpha adrenergic receptor of a peripheral vascular system, which might cause vasodilatation and increase hydrostatic pressure in the blood capillaries, resulting in oedema.

As per another theory, risperidone acts as a 5HT-2 receptor antagonist which can potentially increase the level of cyclic AMP, which relaxes the vascular smooth muscle and which in turn causes oedema. ${ }^{5}$

Another possible mechanism is renal dopamine receptor (D4)-mediated altered regulation of fluid and electrolyte balance by the kidney due to dopaminergic blockade. In case of risperidone-induced angio-oedema, researchers cited other possible reasons such as allergic reactions and altered complement levels. ${ }^{67}$

More studies are required to elucidate the exact mechanism, risk factors, dose dependence and characteristics of risperidone-induced oedema. Clinicians need to be aware about this important side effect, which is usually overlooked by physicians unless the patient complains, as it can negatively affect patients' compliance and quality of life.

Contributors AT, PR: observation and conceptualisation of the case. AT, VN: detailed the assessment, evaluated and concluded the case. RR, VN: manuscript writing, proof-reading and literature review.

Funding The authors have not declared a specific grant for this research from any funding agency in the public, commercial or not-for-profit sectors.

Competing interests None declared.

Patient consent for publication Obtained.

Provenance and peer review Not commissioned; externally peer reviewed.

Open access This is an open access article distributed in accordance with the Creative Commons Attribution Non Commercial (CC BY-NC 4.0) license, which permits others to distribute, remix, adapt, build upon this work non-commercially, and license their derivative works on different terms, provided the original work is properly cited, appropriate credit is given, any changes made indicated, and the use is non-commercial. See: http://creativecommons.org/licenses/by-nc/4.0/.

\section{REFERENCES}

1 Naranjo CA, Busto U, Sellers EM, et al. A method for estimating the probability of adverse drug reactions. Clin Pharmacol Ther 1981;30:239-45.

2 Katz IR, Jeste DV, Mintzer JE, et al. Comparison of risperidone and placebo for psychosis and behavioral disturbances associated with dementia: a randomized, double-blind trial. risperidone Study Group. J Clin Psychiatry 1999;60:107-15.

3 Sanders RD, Lehrer DS. Edema associated with addition of risperidone to valproate treatment. J Clin Psychiatry 1998;59:689-90.

4 Ravasia S. Risperidone-Induced edema. Can J Psychiatry 2001;46:453-4.

5 Tamam L, Ozpoyraz N, Unal M. Oedema associated with risperidone. Clin Drug Investig 2002;22:411-4.

6 Cooney C, Nagy A. Angio-Oedema associated with risperidone. BMJ 1995;311:1204.

7 Terao T, Kojima H, Eto A. Risperidone and allergic reactions. J Clin Psychiatry 1998;59:82-3. 


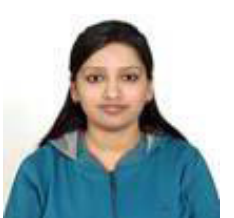

Dr. Arpita Thakur is a third year post graduate resident at M.G.M Medical College Indore, M.P affiliated to MPMS University Jabalpur, M.P, India. She has completed her bachelor's degree of M.B.B.S from Gajra Raja Medical College affiliated to Jiwaji University in Gwalior, M.P., India. She is currently working as an academic resident in a multispecialty hospital in association with a tertiary mental hospital and de-addiction centre. Her thesis dissertation is on serum calcium and magnesium levels in depression and is currently being researched further. Her main research interests include depression, suicide, substance use disorder, and child psychiatry and consultation liaison. 